\title{
Effect of Effective Microorganisms (Em) and Molasses, Wheat Bran, and their Mixture in a Biofloc System on Microbial Protein Production, Water Quality, Growth Performance and Feed Utilization of Nile Tilapia (Oreochromis niloticus) Fingerlings. \\ Aly, M. H. ${ }^{1}$; M. A. Zaki ${ }^{2}$; A.T. Mansour ${ }^{1}$; T. M. Srour ${ }^{1}$ and Eglal A. Omar ${ }^{1}$ \\ ${ }^{1}$ Department of Animal and Fish Production, Faculty of Agriculture (Saba Basha), Alexandria \\ University, Alexandria, Egypt. \\ ${ }^{2}$ Department of Animal Production, Faculty of Agriculture (EI Shatby), Alexandria \\ University, Alexandria, Egypt.
}

\begin{abstract}
The present experiment was carried out to investigate the effect of effective microorganisms, EM; carbohydrate sources as molasses, M; wheat bran, and their mixture in a Bio-floc (BF) system on microbial protein production, water quality, growth performance, and feed utilization of Nile tilapia (Oreochromis niloticus) fingerlings. Seven experimental treatments were designed as following: T1: control, fish were fed a basal diet without any addition of carbohydrate source. T2: T1 plus effective microorganisms (EM) in water media. T3: T1 with supplementary molasses (M) in water media. T4: T1 with supplementary wheat bran (WB) in water media. T5: T1 with supplementary of mixture from EM and M in the water media. T6: T1 with supplementary of mixture from EM and WB in the water media, and T7: T1 with supplementary of mixture from M and WB in the water media. Fish in each tank were fed with one of the experimental diets containing $22.49 \%$ crude protein and 471.60 Kcal. gross energy $/ 100 \mathrm{~g} \mathrm{DM}$ at feeding rate of $3 \%$ of the actual fish live body weight, two times daily (9.00am and $2.00 \mathrm{pm}) \mathrm{for}$ six days a week for 90 days experimental period. Fish were distributed randomly into fourteen indoor fiberglass tanks. Each treatment was conducted in two indoor circular fiberglass tanks of $1 \mathrm{~m}$ diameter filled with 1000 litter of fresh water. Nile tilapia fingerlings with an average initial body weight of $47.5 \pm 0.05$ (g/fish) were randomized stocked at the rate of 42 fish / tank. The results showed the followings:The water quality parameters showed no significant differences in water temperature $\left(\mathrm{C}^{0}\right), \mathrm{pH}$ value and DO (mg/l); however, there were marked differences in the values of total ammonia nitrogen (TA-N, mg/l) and Bio-floc (BF) concentrations (mg/l), with high values of TA-N and BF in tanks' water supplemented with different carbohydrate sources than control, especially with T6 which containing mixture of EM and WB in water media followed by T4 (WB), T3 (M), T5 $(\mathrm{EM}+\mathrm{M}), \mathrm{T} 2(\mathrm{EM})$, and $\mathrm{T} 6(\mathrm{M}+\mathrm{WB})$, respectively compared with $\mathrm{T} 1$ (control without carbohydrate source).Fish growth performance and feed utilization were significantly $(\mathrm{P} \leq 0.05)$ increased with EM and carbohydrate source supplementation than control. Also, T6 which containing a mixture of EM and WB gave the highest performance followed by WB (T4) and M (T3), respectively.Finally, the present results recommended the use of a mixture of effective microorganisms and wheat bran as a carbohydrate source in fish water tanks for optimal performance with best impacts on intensive tilapia culture reared under zero water exchange system.
\end{abstract}

Keywords: Effective microorganisms, carbon sources, Nile tilapia, water quality, growth performance.

\section{INTRODUCTION}

Nile tilapia, Oreochromis niloticus, represents the main Egyptian aquaculture production (GFARD, 2015). Tilapia production can be done in different farming systems including integrated, intensive and superintensive system, also the biofloc technology systems (BFT) (Pérez-Fuentes et al., 2016). The BFT system is a stimulation of aerobic and heterotrophic biota via fertilization with organic carbon source and vigorous water aeration which is conducted under zero water exchange or minimal water changes rate (Rurangwa and Verdegem, 2015).

The selection of carbon source depends on several criteria such as, local availability, cost, biodegradability and assimilation efficiency by bacteria. Commonly, the by-products derived from animal or human food industry usually used as carbon source (Labib, 2016). The Most used carbon source could be used is grain, sugar, molasses, sugarcane bagasse, chopped hay and tapioca (Ahmed et al., 2016 and Labib, 2016).

Moreover, the microorganisms in the biofloc communities allow controlling the inorganic nitrogen levels in fish culture water, which in turn produce microbial biomass ingested by fish and reduce the loss of nitrogen in the aquaculture systems (Wang et al., 2015).
Nearly similar technology is effective microorganisms (EM) which was developed previously in University of Ryukyus, Japan, before forty years (Sangakkara, 2002). The EM technology is a multiculture of aerobic and anaerobic beneficial bacteria, these species produce organic acids, enzymes, antioxidants, and metallic chelates (Zhao et al., 2006).

Therefore the present study was aimed to investigate the effect of EM addition in the rearing water with different carbon sources (molasses, wheat bran, and their mixture) on Water quality, growth performance, and feed utilization of Nile tilapia ( $O$. niloticus) fingerlings.

\section{MATERIALS AND METHODS}

The present study was performed at the Laboratory of Fish Nutrition, Faculty of Agriculture (Saba Basha) in cooperation with National Institute of Oceanography and Fisheries (NIOF), El Max Research Station , Alexandria , Egypt , throughout the period from 4 August to 5 November 2016 (90 days) to investigate the effect of effective microorganisms, EM; carbohydrate sources (wheat bran, WB and molasses, $\mathrm{M}$ and their mixture) in a biofloc system on water quality, growth performance, feed utilization of Nile tilapia, Oreochromis niloticus, fingerlings. 


\section{Experimental facility}

At the start of the experiment, a total number of 588 healthy fish were chosen. Fish were obtained from a private commercial fresh water fish farm sited in Motobas, Kafr-ElSheikh governorate, Egypt. Prior to the start of the experiment, experimental fish were kept for two weeks in circular fiberglass tanks $(1$ cubic meter) as an acclimation period and fed a control basal diet Table 1.

Table 1. Feed ingredients and proximate chemical analysis of the experimental diet.

\begin{tabular}{|c|c|}
\hline Ingredients (g $100 \mathrm{~g}_{-}{ }^{1}$ ) & Experimental diet \\
\hline Soybean meal (46\%) & 10 \\
\hline Corn gluten meal $(60 \%)$ & 15 \\
\hline Rice bran & 14 \\
\hline Wheat bran & 10 \\
\hline Yellow corn & 46 \\
\hline Sun flower oil & 2 \\
\hline L. Lysine & 0.5 \\
\hline L. Methionine & 0.5 \\
\hline Vitamins $^{1}$ and minerals mixture ${ }^{2}$ & 2 \\
\hline Total & 100 \\
\hline \multicolumn{2}{|c|}{ Chemical composition $(\%)$ on dry matter basis } \\
\hline Dry matter (DM) & 95.30 \\
\hline Crude protein $(\mathrm{CP})$ & 22.49 \\
\hline Ether extract (EE) & 11.50 \\
\hline Crude fiber (CF) & 4.11 \\
\hline Ash & 4.56 \\
\hline Nitrogen free extract (NFE) ${ }^{3}$ & 57.44 \\
\hline Gross energy (GE; kcal/100g DM $\left.{ }^{4}\right)$ & 471.60 \\
\hline $\mathrm{P} / \mathrm{E}$ ratio $(\mathrm{mg} \mathrm{CP} / \mathrm{kcal})^{5}$ & 47.65 \\
\hline \multicolumn{2}{|c|}{$\begin{array}{l}\text { Vitamin mixture/kg premix containing the following: vitamin A } \\
3300 I U \text {, vitamin D3 } 410 \mathrm{IU} \text {, vitamin E } 2660 \mathrm{mg} \text {, vitamin B1 } \\
133 \mathrm{mg} \text {, vitamin B2 } 580 \mathrm{mg} \text {, vitamin B6 } 410 \mathrm{mg} \text {, vitamin B12 } \\
50 \mathrm{mg} \text {, biotin } 9330 \mathrm{mg} \text {, colin chloride } 4000 \mathrm{mg} \text {, vitamin C } 2660 \\
\mathrm{mg} \text {, inositol } 330 \mathrm{mg} \text {, para- amino benzoic acid } 9330 \mathrm{mg} \text {, niacin } \\
26.60 \mathrm{mg} \text {, and pantothenic acid } 220 \mathrm{mg} \text {. }\end{array}$} \\
\hline \multicolumn{2}{|c|}{$\begin{array}{l}\text { Mineral mixture/kg premix containing the following: } 325 \mathrm{mg} \\
\text { Manganese, 200mg Iron, 25mg Copper, } 5 \mathrm{mg} \text { Iodine, and } 5 \mathrm{mg} \\
\text { Cobalt. }\end{array}$} \\
\hline \multicolumn{2}{|c|}{$\mathrm{NFE}=$ nitrogen free extract. } \\
\hline \multicolumn{2}{|c|}{$\begin{array}{l}{ }^{4} \mathrm{GE}=\text { Gross Energy: was calculated as } 5.65,9.45 \text { and } 4.12 \mathrm{Kcal} \text { per } \\
\text { gram of protein, lipid and carbohydrate, respectively after } \\
\text { NRC (2011). }\end{array}$} \\
\hline
\end{tabular}

Fish were distributed randomly into fourteen indoor fiberglass tanks. Each treatment was conducted in two indoor circular fiberglass tanks, each of $1 \mathrm{~m}$ diameter filled with 1000 litter of fresh water with an exchange rate of $20 \%$ / tank daily for T1 only; however, zero water exchange was applied in the other treatments. Nile tilapia fingerlings with an average initial body weight of $47.5 \pm 0.05$ (g/fish) were randomized stocked at the rate of 42 fish / tank. Continuous aeration was conducted by pumping air into the water in the tank bottom using two sandy diffusers. Rearing water temperature was maintained between 27.0 and $28.0{ }^{\circ} \mathrm{C}$ by using electrical heaters. The light period was maintained for only twelve hours; while in the other twelve hours were maintained dark. Effective microorganisms and carbohydrate sources (WB and M and their mixture) were added daily to water of each tank in order to adjust the $\mathrm{C} / \mathrm{N}$ ratio of water to $20: 1$ (T2, T3, T4, T5 ,T6 and T7); however, no carbohydrate source was added to T1 (control) . The EM product is produced in the Ministry of Agriculture, Egypt with the co-operation between the Egyptian government and the Japanese Embassy in Egypt. The EM accelerates the natural decomposition of organic matter using 3 wellknown groups of microorganisms: mainly (1) lactic acid bacteria (2) yeasts and (3) phototrophic or photosynthetic bacteria (from green seaweed and in any soil particle). The microorganisms in EM are beneficial and highly efficient; they are not harmful, not pathogenic, not genetically modified and not chemically synthesized. They are well known natural microorganisms; yeasts and lactic acid bacteria (Lactobacillus) promote the process of beneficial antioxidative fermentation, accelerate the decomposition of organic matter, and promote the balance of the microbial flora (Kolk and Smink, 2005 and Kriangsak, 2001). They are also beneficial microorganisms which are helpful in the aquaculture productive systems. Effective microorganisms and carbohydrate sources (WB and $\mathrm{M}$ and their mixture) were added daily to water of each tank in order to adjust the $\mathrm{C} / \mathrm{N}$ ratio of water to 20:1 (T2, T3, T4, T5 ,T6 and T7); however, no carbohydrate source was added to T1 (control) .

\section{Fish and experimental design}

This experiment consists of seven treatments were designed in randomized as the following: $T_{1}$ : control, fish were fed a basal diet without carbohydrate source was added. T2: as T1 with EM supplementation in water media. T3:T1 with supplementary $\mathrm{M}$ in water media. T4: T1 with supplementary WB in water media. T5: T1 with supplementary a mixture of EM and M in the water media. T6: T1 with supplementary a mixture of EM and WB in the water media, and T7: T1 with supplementary a mixture of $\mathrm{M}$ and $\mathrm{WB}$ in the water media.

Preparation of microbial protein production

Molasses and wheat bran were used based on the promotion of bacteria as the main primary producers by the use of carbon sources and substrates. The sugarcane molasses was used in this study as an external carbon source to improve reactor stability and increase chemical oxygen demand. Carbon was added at the rate of 20 times the concentration of total ammonia nitrogen (TAN) concentration in the tank's water to maintain appropriate $\mathrm{C}$ : $\mathrm{N}$ ratio for optimum production of microbial protein system (Avnimelech, 1999).

It is possible to theoretically (the following schema) calculate the amount of organic matter needed for an intensive pond, based on the amount of nitrogen excreted by the aquaculture species. Carbohydrate sources were added daily according to nitrogen excreted in the fish for manipulation the $\mathrm{C}: \mathrm{N}$ ratio in order to raise the $\mathrm{C}$ : $\mathrm{N}$ ratio to $20: 1$. 
Daily feeding of $2 \%$ of fish weight (Craig and Helfrich, 2002)

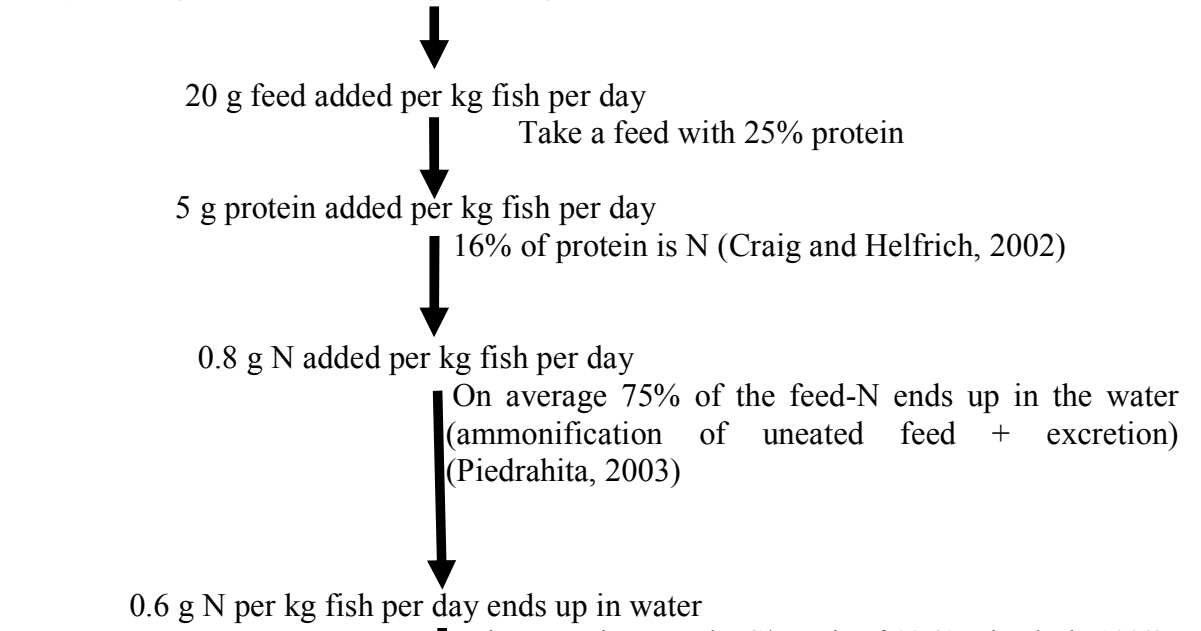

$6 \mathrm{~g} \mathrm{C}$ per kg fish per day needed for biofloc production

Daily dosage of organic compound $15 \mathrm{~g}$ dry matter $/ \mathrm{d}$.

The bases of calculating the wasted of nitrogen in water and carbon added (Crab et al., 2012).

\section{Experimental diet}

An experimental diet $(22.5 \%$ crude protein and $471.6 \mathrm{kcal}$ GE/100 g DM diet) was formulated using plant protein sources without any addition of fish meal (Table 1). Dietary ingredients were ground and thoroughly mixed and the oil was slowly added at the same time of mixing with warm water $\left(45^{\circ} \mathrm{C}\right)$ until the diet began to clump. The diet was then processed by a California pellet mill machine and dried for 48 hours in a drying oven at $70^{\circ} \mathrm{C}$. The pellet size was $0.3 \mathrm{~mm}$ in diameter and $2 \mathrm{~mm}$ in length. Fish were fed two times daily (9.00: $14.00 \mathrm{hrs),6}$ days a week for 90 days. Feeding rate was $3 \%$ of fresh body weight. Fish were weighed at two weeks interval and the amounts of feed were readjusted according to fish weight. Fish samples were collected at the beginning and the end of the experiment and store frozen at $-20^{\circ} \mathrm{C}$ until whole body chemicals analysis.

\section{Measurements of biofloc volume}

Bio-floc volume was determined using Imhoff cones fortnight, the volume taken in by the flocs in 1000 $\mathrm{ml}$ of the tank water after $30 \mathrm{~min}$ sedimentation were registered (Avnimelech and Kochba, 2009).

Fish performance and feed utilization parameters

Fish growth performance and feed utilization parameters were calculated according to Cho and Kaushik (1985) from following equations:

1) Average weight gain $(\mathrm{AWG}, \mathrm{g} / \mathrm{fish})=[$ final body weight-initial body weight];

2) Average daily gain (ADG, g / fish / day) = [AWG/time (days)];

3) Specific growth rate (SGR, \% / day) $=[\ln$ final weight $-\ln$ initial weight] $\times 100 /$ time (days);

4) Feed conversion ratio $(\mathrm{FCR})=$ feed intake $(\mathrm{g}) /$ body weight gain $(\mathrm{g})$;
5) Protein efficiency ratio $($ PER $)=$ gain in weight $(\mathrm{g}) /$ protein intake in feed $(\mathrm{g})$;

6) Protein productive value $(\mathrm{PPV}, \%)=100$ [protein gain in fish $(\mathrm{g}) /$ protein intake in feed $(\mathrm{g})]$;

7) Energy utilization $(\mathrm{EU}, \%)=100$ [energy gain in fish (Kcal) / energy intake in feed (Kcal)]; and

8) Survival rate $(\mathrm{SR}, \%)=100 \mathrm{x}$ (total number of fish survived/total number of fish stocked).

\section{Chemical analysis}

Chemical analysis of experimental diet and fish carcass was conducted in order to determine the percentages of dry matter (DM \%), crude protein (CP $\%$ ), ether extract (EE \%), crude fiber (CF \%), and ash (Ash \%) according to the AOAC (2000) method. Nitrogen free extract (NFE \%) was calculated by differences, by deducting the sum of percentages of moisture, CP, EE, CF and ash from 100. Gross energy ( $\mathrm{kcal} / \mathrm{g}$ DM, GE) contents of the experimental diets and fish samples were calculated by using factors of 5.65, 9.45 and $4.12 \mathrm{kcal} / \mathrm{g}$ of protein, lipid and carbohydrates, respectively (NRC, 2011).

\section{Statistical analysis}

Experimental data were statistically analyzed with one-way ANOVA and Duncan's (1955) multiple range tests and expressed as mean values \pm SE. Effects with a probability of $\mathrm{P}<0.05$ were considered significant. Statistical analyses were performed using SPSS for Windows (Standard Version 17 SPSS Inc. Chicago, Illinois).

\section{RESULTS AND DISCUSSION}

\section{Water quality}

The effect of EM and carbon sources in a biofloc system on water quality of Nile tilapia after 90 days rearing period was showed in Table 2 . The water quality parameters monitored throughout the experimental 
period (temperature, $\mathrm{pH}$ and $\mathrm{DO})$ were not affected $(\mathrm{P} \geq$ $0.05)$ by any of the conducted treatments. All the environmental variables during the study period were within the range considered suitable for the culture of Nile tilapia. A temperature in water of all treatment was in optimal condition for the fish culture which ranged from 26.90 to $27.1^{0} \mathrm{C}$. Tekeliogla (1998) recommended a preferred temperature values for tilapia between 20 to $35^{\circ} \mathrm{C}$. The $\mathrm{pH}$ were lower in the $\mathrm{T} 2$ treatment, suggesting a reducing condition in such treatments, probably due to the activity of heterotrophic bacteria, which release $\mathrm{CO}_{2}$ to the water column causing a $\mathrm{pH}$ decrease (El-Kady et al., 2016). Dissolved oxygen remained within the recommended range for growth of tilapia. By aerating the DO, the average was kept above $5 \mathrm{mg} / \mathrm{l}$. This value is within the recommended levels as reported by El-Sayed (2006). The incidents of increased TAN were higher in all treatments compared to group number $\mathrm{T} 1$. The differences in TAN concentrations between all treatments as expected, as there is increase in the heterotrophic bacteria activities in BFT treatment which process to decrease TAN by nitrification (ElKady et al., 2016). Within the BFT treatments, nitrate-N gradually decreased in all treatment, this may be explained by the low dose of nitrogen delivered for the system (Nieuwenhuiz, 2000).

Table 2. Effect of effective microorganisms and carbon sources in biofloc system on water quality and biofloc volume of Nile Tilapia.

Treatment $^{*}$ Temperature pH $^{\text {DO }^{1}}$ TAN $^{2}$ Biofloc $\left({ }^{\circ} \mathrm{C}\right) \quad(\mathrm{mg} / \mathrm{l})(\mathrm{mg} / \mathrm{l})$ volume

\begin{tabular}{cccccc} 
& & & & & $(\mathbf{m g} / \mathbf{l})$ \\
\hline T1 & 26.91 & 7.90 & 5.47 & $1.20^{\mathrm{c}}$ & $1.40^{\mathrm{e}}$ \\
& \pm 0.05 & \pm 0.10 & \pm 0.58 & \pm 0.20 & \pm 0.20 \\
T2 & 26.90 & 7.80 & 5.44 & $2.31^{\mathrm{ab}}$ & $12.10^{\mathrm{c}}$ \\
& \pm 0.04 & \pm 0.01 & \pm 0.09 & \pm 0.10 & \pm 1.70 \\
$\mathrm{~T} 3$ & 27.10 & 7.93 & 5.55 & $2.22^{\mathrm{ab}}$ & $17.80^{\mathrm{b}}$ \\
& \pm 0.09 & \pm 0.09 & \pm 0.09 & \pm 0.24 & \pm 1.07 \\
$\mathrm{~T} 4$ & 26.90 & 7.94 & 5.45 & $1.87^{\mathrm{abc}}$ & $23.00^{\mathrm{a}}$ \\
& \pm 0.10 & \pm 0.08 & \pm 0.04 & \pm 0.17 & \pm 1.00 \\
$\mathrm{~T} 5$ & 26.90 & 8.04 & 5.53 & $2.30^{\mathrm{ab}}$ & $15.13^{\mathrm{bc}}$ \\
& \pm 0.07 & \pm 0.06 & \pm 0.05 & \pm 0.20 & \pm 0.80 \\
$\mathrm{~T} 6$ & 27.10 & 8.00 & 5.55 & $1.67^{\mathrm{bc}}$ & $23.90^{\mathrm{a}}$ \\
& \pm 0.12 & \pm 0.05 & \pm 0.03 & \pm 0.17 & \pm 1.77 \\
$\mathrm{~T} 7$ & 27.10 & 8.03 & 5.44 & $2.45^{\mathrm{a}}$ & $7.87^{\mathrm{d}}$ \\
& \pm 0.13 & \pm 0.14 & \pm 0.07 & \pm 0.26 & \pm 0.87 \\
\hline
\end{tabular}

${ }^{\bar{*}}$ Means in the same column having different letters are significantly $(\mathrm{P} \leq 0.05)$ different. ${ }^{1} \mathrm{DO}$ : Dissolve oxygen and ${ }^{2}$ TAN=Total ammonia nitrogen

\section{Growth performance}

The effect EM, as well as EM and different carbon sources in biofloc system on growth performance of Nile tilapia after three months rearing period is shown in Table 3. Results showed that initial weights had ranged between $47.55 \pm 0.07$ and $50.25 \pm$ $0.25 \mathrm{~g} /$ fish with insignificant differences among treatments indicating complete randomization of dividing the fish into experiments groups. Averages of final weight $(\mathrm{FW})$, average daily gain (ADG), specific growth rate (SGR), and relative growth rate (RGR) for the experimented groups (T1-T7) were significantly $(\mathrm{P} \leq 0.05)$ affected by additives of $\mathrm{T} 6(\mathrm{EM}+\mathrm{WB})$ and $\mathrm{T} 4$
(WB) in a biofloc system released the highest final body weight, being $121.64 \pm 1.88$ and $110.08 \pm 2.08 \mathrm{~g} /$ fish, respectively. In the same trend, ADG and SGR showed significant differences among most treatment and recorded the highest values in treatments T6 and T4, being the values were 0.82 and $0.66 \mathrm{~g} /$ fish/day and 1.05 and $0.87 \% /$ day, respectively. On the other hand, the lowest values were recorded with the treatments $\mathrm{T} 1, \mathrm{~T} 2$, T3, T5, and T7. Different studies have reported enhanced growth rates of fish raised in ponds with high activity of algae, microbial biofloc, and other natured biota (Moss et al., 2001 and Burford et al., 2004).

However, it is not yet known exactly how microbial biofloc enhance growth. But, Lzquierdo et al. (2006) suggested lipid contributions of microbial biofloc that are significant. Moreover, Avnimelech, 1999 and El-Kady et al. (2016) reported that the microbial protein supplied by the storied fish biomass was enough to supplement the protein provided by the fish feed. In culture system together with microbial biofloc acting as a feed also do play some important ecological values. The deterioration of water quality due to unconsumed feed, fecal matter of cultured organisms or the presence of other organic matter in culture facilities in nullified because the biofloc microbes act as conditioner for water (El-Kady et al., 2016 and Mansour and Esteban, 2017). Also, O. niloticus fed different dietary protein ( 24 and $35 \%$ ) and reared under biofloc systems did not showed any significant changes in growth performance (Azim, 2008). The improvement in growth afforded by biofloc system in the present study would be due to the abundance of active heterotrophic bacteria which can assimilate the waste nitrogen and produce new cellular protein for fish consumption as previously indicated (Crab et al., 2012 and Long et al., 2015).

Table 3. Effect of effective microorganisms and carbon sources in biofloc system on growth performance of Nile tilapia.

\begin{tabular}{|c|c|c|c|c|c|}
\hline " & 绨 & 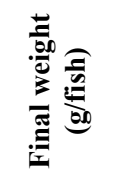 & 氞 & 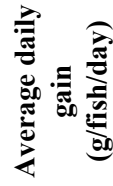 & 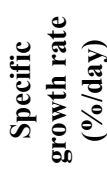 \\
\hline \multirow[t]{2}{*}{$\overline{\mathrm{T} 1}$} & $49.22^{\mathrm{ab}}$ & $76.62^{d}$ & $27.41^{\mathrm{d}}$ & $0.30^{\mathrm{d}}$ & $0.49^{\mathrm{d}}$ \\
\hline & \pm 0.88 & \pm 0.58 & \pm 0.31 & \pm 0.01 & \pm 0.01 \\
\hline \multirow[t]{2}{*}{$\mathrm{T} 2$} & $49.24^{\mathrm{ab}}$ & $94.09^{c}$ & $44.84^{\mathrm{c}}$ & $0.50^{\mathrm{c}}$ & $0.72^{\mathrm{c}}$ \\
\hline & \pm 0.91 & \pm 1.51 & \pm 0.61 & \pm 0.01 & \pm 0.01 \\
\hline \multirow[t]{2}{*}{$\mathrm{T} 3$} & $47.50^{b}$ & $97.30^{\mathrm{c}}$ & $49.80^{\mathrm{bc}}$ & $0.55^{\mathrm{bc}}$ & $0.80^{\mathrm{bc}}$ \\
\hline & \pm 0.26 & \pm 3.70 & \pm 3.96 & \pm 0.04 & \pm 0.05 \\
\hline \multirow[t]{2}{*}{$\mathrm{T} 4$} & $50.25^{\mathrm{a}}$ & $110.08^{b}$ & $59.83^{\mathrm{b}}$ & $0.66^{\mathrm{b}}$ & $0.87^{\mathrm{b}}$ \\
\hline & \pm 0.25 & \pm 2.08 & \pm 2.33 & \pm 0.03 & \pm 0.03 \\
\hline \multirow[t]{2}{*}{ T5 } & $47.60^{\mathrm{b}}$ & $96.36^{c}$ & $48.76^{\mathrm{c}}$ & $0.54^{\mathrm{c}}$ & $0.78^{\mathrm{bc}}$ \\
\hline & \pm 0.21 & \pm 5.64 & \pm 5.86 & \pm 0.07 & \pm 0.07 \\
\hline \multirow[t]{2}{*}{ T6 } & $47.55^{b}$ & $121.64^{\mathrm{a}}$ & $74.10^{\mathrm{a}}$ & $0.82^{\mathrm{a}}$ & $1.05^{\mathrm{a}}$ \\
\hline & \pm 0.07 & \pm 1.88 & \pm 1.81 & \pm 0.02 & \pm 0.02 \\
\hline \multirow[t]{2}{*}{$\mathrm{T} 7$} & $47.62^{b}$ & $89.14^{c}$ & $41.52^{\mathrm{c}}$ & $0.46^{\mathrm{c}}$ & $0.70^{\mathrm{c}}$ \\
\hline & \pm 0.00 & \pm 3.38 & \pm 3.38 & \pm 0.04 & \pm 0.05 \\
\hline
\end{tabular}

"Means in the same column having different letters are significantly $(\mathrm{P} \leq \mathbf{0 . 0 5})$ different.

T1:control,T2 (EM: Effective microorganisms), T3 (M): Molasses, T4:(WB): Wheat bran, T5: EM+M, T6:EM+WB, and T7: M+WB. 


\section{Feed utilization}

The effect of EM and carbon sources in biofloc system on feed and nutrient utilization of Nile tilapia after three months rearing period is shown in Table 4. Results showed that feed intake had ranged between 79.51 and $102.52 \mathrm{~g} /$ fish with insignificant differences among treatments indicating complete randomization of dividing the fish into experiments groups. Moreover, the FCR improved significantly with all studied treatments compared to the control (T1). The best FCR was obtained in T6 (EM+WB) followed by T4 (WB). In the same trend, PER, PPV and EU showed significant differences among most treatment and recorded the highest values in treatments $\mathrm{T} 6$ and $\mathrm{T} 4$, being the values were 3.22 and 2.55; 56.54 and $34.50 \%$; and 27.53 and 19.48 , respectively. On the other hand, the lowest values were recorded with the treatments T1and T2. The results obtained for FI, FCR, PER, and PPV in this study agree with the findings of Xia et al. (2010) and El-Kady et al. (2016). Who reported the effect of biofloc, feeding rate and dietary protein level on growth performance and feed utilization of Nile tilapia, flathead grey mullet and thin lipped mullet in poly-culture. The results revealed significant differences for the effect of dietary protein level in biofloc system on growth performance and feed utilization. Overall, the beneficial effects of probiotics on fish performance parameters were in agreement with the findings of Wang et al. (2008) who studied the effect of using probiotics in tilapia compared with studies lacking positive effects (Shelby et al., 2006).

Table 4. Effect of effective microorganisms and carbon sources in biofloc system on feed and nutrients utilization of Nile tilapia.

\begin{tabular}{cccccc}
\hline Treatments $^{*}$ & $\begin{array}{c}\text { Feed intake } \\
\text { (g/fish) }\end{array}$ & FCR $^{\mathbf{1}}$ & PER $^{\mathbf{2}}$ & $\begin{array}{c}\mathbf{P P V}^{\mathbf{3}} \\
\mathbf{( \% )}^{\mathbf{\%}}\end{array}$ & $\mathbf{E U}^{\mathbf{4} \%}$ \\
\hline $\mathrm{T} 1$ & $79.51^{\mathrm{c}}$ & $2.90^{\mathrm{a}}$ & $1.55^{\mathrm{d}}$ & $15.90^{\mathrm{d}}$ & $12.63^{\mathrm{cd}}$ \\
& \pm 1.53 & \pm 0.09 & \pm 0.01 & \pm 1.31 & \pm 1.79 \\
$\mathrm{~T} 2$ & $85.19^{\mathrm{bc}}$ & $1.90^{\mathrm{bc}}$ & $2.36^{\mathrm{bc}}$ & $45.83^{\mathrm{b}}$ & $22.93^{\mathrm{ab}}$ \\
& \pm 1.21 & \pm 0.05 & \pm 0.01 & \pm 0.01 & \pm 0.05 \\
$\mathrm{~T} 3$ & $88.34^{\mathrm{b}}$ & $1.78^{\mathrm{c}}$ & $2.53^{\mathrm{bc}}$ & $37.16^{\mathrm{bc}}$ & $18.27^{\mathrm{bc}}$ \\
& \pm 3.67 & \pm 0.07 & \pm 0.15 & \pm 3.80 & \pm 1.54 \\
$\mathrm{~T} 4$ & $102.52^{\mathrm{a}}$ & $1.72^{\mathrm{cd}}$ & $2.55^{\mathrm{bc}}$ & $34.50^{\mathrm{bc}}$ & $19.48^{\mathrm{b}}$ \\
& \pm 0.73 & \pm 0.05 & \pm 0.07 & \pm 0.49 & \pm 0.44 \\
$\mathrm{~T} 5$ & $84.68^{\mathrm{bc}}$ & $1.76^{\mathrm{c}}$ & $2.58^{\mathrm{b}}$ & $45.83^{\mathrm{b}}$ & $22.05^{\mathrm{ab}}$ \\
& \pm 0.69 & \pm 0.23 & \pm 0.28 & \pm 0.01 & \pm 3.68 \\
$\mathrm{~T} 6$ & $100.78^{\mathrm{a}}$ & $1.36^{\mathrm{d}}$ & $3.22^{\mathrm{a}}$ & $56.54^{\mathrm{a}}$ & $27.53^{\mathrm{a}}$ \\
& \pm 1.28 & \pm 0.05 & \pm 0.13 & \pm 2.77 & \pm 1.66 \\
$\mathrm{~T} 7$ & $90.05^{\mathrm{b}}$ & $2.18^{\mathrm{b}}$ & $2.06^{\mathrm{c}}$ & $21.99^{\mathrm{d}}$ & $9.30^{\mathrm{d}}$ \\
& \pm 3.34 & \pm 0.10 & \pm 0.14 & \pm 3.15 & \pm 1.15 \\
\hline
\end{tabular}

"Means in the same column having different letters are significantly $(\mathrm{P} \leq \mathbf{0 . 0 5})$ different. $\mathrm{T} 1$ : control, $\mathrm{T} 2$ (EM: Effective microorganisms), T3 (MO): Molasses, T4: (WB): Wheat bran, T5: EM+M, T6: EM+WB, T7: M+WB. ${ }^{1}$ FCR: Feed conversion ratio, ${ }^{2}$ PER: Protein efficiency ratio, and ${ }^{3} \mathrm{PPV}$ : Protein productive value and ${ }^{4} E U$ : energy utilization.

However, there were no significant differences in growth and utilization of treating with $B$. subtilis compared with the control (Body and Tucker, 2009). Biofloc systems therefore represent a suitable culture condition for growth and feed utilization of $O$. niloticus without any obvious negative effect on water quality or fish survival, which reflects previous findings concerning the positive effect of biofloc on the growth performance of cultured fish and shrimp (Arnold et al., 2009; Wang et al., 2015 and Verma et al., 2016). The suitability of using biofloc at $4 \%$ level of dietary supplementation for improving growth, FCR and digestive enzyme activities has been demonstrated in Penaeus monodon (Anand et al., 2013).

Body composition:

The effect of EM and carbon sources in biofloc system on proximate chemical composition of Nile tilapia after three months rearing period is shown in Table 5. Results of this Table reveal that DM contents ranged between 28.16 and $28.70 \%$ with insignificant differences among the dietary treatment groups. The same Table reflects a significant increase in crude protein in T6 compared with T1 (59.00 and 49.30\%, respectively). In the same Table, average of ether extract content was found to be higher at the end of experimented with T4, T1, T2 and T5 and there were no significant differences $(\mathrm{P} \geq 0.05)$.

Table 5. Effect of effective microorganisms and carbon sources in biofloc system on body chemical composition of Nile tilapia.

\begin{tabular}{|c|c|c|c|c|c|}
\hline \multirow{2}{*}{ 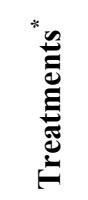 } & \multirow[b]{2}{*}{$\mathbf{D M}^{1}$} & \multicolumn{3}{|c|}{$\%$ on dry matter basis } & \multirow[b]{2}{*}{$\begin{array}{l}\text { Energy } \\
\text { content }\end{array}$} \\
\hline & & $\mathbf{C P}^{2}$ & $\mathbf{E E}^{3}$ & ASH & \\
\hline T1 & $28.16^{\mathrm{d}}$ & $49.30^{\mathrm{f}}$ & $27.70^{\mathrm{ab}}$ & $23.00^{\mathrm{a}}$ & $539.40^{d}$ \\
\hline $\mathrm{T} 2$ & $\begin{array}{c}28.52^{\mathrm{b}} \\
\pm 0.03\end{array}$ & $\begin{array}{l}57.75^{\mathrm{b}} \\
\pm 0.35\end{array}$ & $\begin{array}{c}27.30^{\mathrm{ab}} \\
\pm 0.70\end{array}$ & $\begin{array}{l}14.95^{\mathrm{d}} \\
\pm 0.35\end{array}$ & $\begin{array}{c}583.42^{\mathrm{a}} \\
\pm 4.68\end{array}$ \\
\hline $\mathrm{T} 3$ & $\begin{array}{c}28.64^{\mathrm{a}} \\
\pm 0.01\end{array}$ & $\begin{array}{l}56.60^{\mathrm{c}} \\
\pm 0.01\end{array}$ & $\begin{array}{c}26.20^{\mathrm{c}} \\
\pm 0.28\end{array}$ & $\begin{array}{l}17.20^{\mathrm{c}} \\
\pm 0.28\end{array}$ & $\begin{array}{c}566.55^{\mathrm{b}} \\
\pm 2.67\end{array}$ \\
\hline $\mathrm{T} 4$ & $\begin{array}{c}28.70^{\mathrm{a}} \\
\pm 0.01\end{array}$ & $\begin{array}{l}53.40^{\mathrm{e}} \\
\pm 0.42\end{array}$ & $\begin{array}{l}27.95^{\mathrm{a}} \\
\pm 0.07\end{array}$ & $\begin{array}{l}18.65^{b} \\
\pm 0.35\end{array}$ & $\begin{array}{l}565.02 \\
\pm 1.72^{b}\end{array}$ \\
\hline T5 & $\begin{array}{c}28.27^{\mathrm{c}} \\
\pm 0.01\end{array}$ & $\begin{array}{l}55.75^{\mathrm{d}} \\
\pm 0.21\end{array}$ & $\begin{array}{c}27.40^{\mathrm{ab}} \\
\pm 0.56\end{array}$ & $\begin{array}{l}16.85^{\mathrm{c}} \\
\pm 0.35\end{array}$ & $\begin{array}{c}547.52^{\mathrm{cd}} \\
\pm 0.01\end{array}$ \\
\hline T6 & $\begin{array}{c}28.31^{\mathrm{c}} \\
\pm 0.04\end{array}$ & $\begin{array}{l}59.00^{\mathrm{a}} \\
\pm 0.14\end{array}$ & $\begin{array}{c}26.65^{b c} \\
\pm 0.63\end{array}$ & $\begin{array}{c}14.35 \\
\pm 0.49^{\mathrm{d}}\end{array}$ & $\begin{array}{c}584.33^{\mathrm{a}} \\
\pm 5.21\end{array}$ \\
\hline $\mathrm{T} 7$ & $\begin{array}{c}28.25^{\mathrm{c}} \\
\pm 0.04\end{array}$ & $\begin{array}{c}58.00^{\mathrm{b}} \\
\pm 0.28\end{array}$ & $\begin{array}{l}23.50^{\mathrm{d}} \\
\pm 0.28^{-}\end{array}$ & $\begin{array}{l}18.50^{b} \\
\pm 0.56\end{array}$ & $\begin{array}{c}548.96^{\mathrm{c}} \\
\pm 4.27\end{array}$ \\
\hline otei & 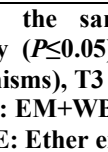 & 1.10 & - & ferent & letters a \\
\hline
\end{tabular}

Also, an average of ash content was found to be higher in the groups T1, T4, and T7; whereas the lowest ash values were found in groups T6, T2, and T3. The higher protein concentration in fish was evaluated in biofloc with wheat bran that may be related to the chemical composition of heterotrophic bacteria and other organisms associated to biofloc and biofilm (Fernández et al., 2008 and El-Kady et al., 2016). The effect of a carbon source on the growth of cultured species depends on some characteristics of the biofloc produced such as its volume, chemical composition, and ability to store bioactive compounds, e.g. polymers, 
catotenoids, phytosterols and extracellular enzymes (De Schryver and Verstraete, 2009 and Zhao et al., 2016). In the present study, the development of biofloc not only maintained the water quality suitable for fish culture under zero water exchange but also could supplement protein nutrition, thereby resulting in high survival and similar growth performance and FCR of the fish fed with $25 \%$ and $30 \%$ dietary protein levels (Kiron, 2012 and El-Kady et al., 2016).

\section{CONCLUSION}

The present results recommended the use of a mixture of effective microorganisms and wheat bran as a carbohydrate source for optimum performance in fish water tanks with best impacts on intensive tilapia culture reared under zero water exchange system.

\section{REFERENCES}

Ahmad.H.; Irshad, A.K., Verma, A.M., Adnan, B.R. and Gora, H. (2016). Growth, non-specific immunity and disease resistance of Labeo rohita against Aeromonas hydrophila in biofloc systems using different carbon sources. Aquaculture, Amsterdam, 457 (20): 61-67.

Anand, P.S.S., Kumar, S., Panigrahi, A., Ghoshal, T.K., Dayal, J.S., Biswas, G., Sundaray, J.K., De, D., Raja, R.A., Deo, A.D., Pillai, S.M. and Ravichandran, P. (2013). Effects of C: N ratio and substrate integration on periphyton biomass, microbial dynamics and growth of Penaeus monodon juveniles. Aquacult. Int., 21: 511-524.

AOAC (2000). Official Methods of Analysis. 17th ed. Gaithersburg, Maryland, USA, AOAC International. Also valid are: a second revision of this edition (2003); the 16th edition (1995) and the 15th edition (1990). This last was published in Arlington, Virginia, USA, by AOAC International.

Arnold, S. J., Coman, F. E., Jackson, C. J., and Groves, S. A. (2009). High-intensity, zero water-exchange production of juvenile tiger shrimp, Penaeus monodon: an evaluation of artificial substrates and stocking density. Aquaculture, 293(1): 42-48.

Avnimelech, Y. (1999). Carbon/ nitrogen ratio as a control element in Aquaculture systems. Aquac., 176: $227-$ 235.

Avnimelech, Y. (1999). Carbon/nitrogen ratio as a control element in aquaculture systems. Aquaculture, 176: 227-235

Avnimelech, Y. and Kochba, M. (2009). Evaluation of nitrogen uptake and excretion by tilapia in bio floc tanks, using $15 \mathrm{~N}$ tracing. Aquaculture, 287 (1): 163-168.

Azim, M. E. and Little, D. C. (2008). The biofloc technology (BFT) in indoor tanks: water quality, biofloc composition, and growth and welfare of Nile tilapia (Oreochromis niloticus). Aquaculture, 283(1): 29-35.

Boyd, C.E. and Tucker, C.S. (2009). Pond aquacultureure water quality management, Springer International Editor, 700 pp.
Burford, M.A., Sellars, M.J., Arnold, S.J., Keys, S.J., Crocos, P.J. and Preston, N.P. (2004). Contribution of the natural biota associated with substrates to the nutritional requirements of the post-larval shrimp, Penaeus esculentus (Haswell), in high-density rearing systems. Aquaculture Research, 35: 508515.

Cho C.Y. and Kaushik, S.J. (1985). Effects of protein intake on metabolizable and net energy values of fish diets. In: Nutrition and feeding in fish, Academic Press, London, 95-117.

Crab, R.; Defoirdt,T., Bossier, P. and Verstraete, W. (2012). Biofloc technology in aquaculture: Beneficial effects and future challenges. Aquaculture, 356-357.

Craig, S. and Helfrich, L. A. (2002). Understanding Fish Nutrition, Feeds and Feeding, Cooperative Extension Service, publication 420-256. Virginia State University, USA.

Duncan, D. B. (1955). Multiple range and multiple F tests. Biometrics, 11: 1-42.

El-Kady, H.A., Omar, E.A., Srour, T.M. and Salem, M.F. (2016). Effect of biofloc, feeding rate and dietary protein levels on growth performance and utilization of Nile tilapia, flathead grey mullet, and thin lipped mullet fingerlings in poly culture. J.Adv.Agric.Res., 21 (1):1-18.

El-Sayed, A. F. M. (2006). Tilapia culture in salt water: environmental requirements, nutritional implications and economic potentials. VIII Simposium Internacional de Nutrición Acuícola. Universidad Autónoma de Nuevo León. Anais. Monterrey. Monterrey.

Fernández, I., Hontoria, F., Ortiz-Delgado, J. B., Kotzamanis, Y., Estévez, A., Zambonino-Infante, J. L. and Gisbert, E. (2008). Larval performance and skeletal deformities in farmed gilthead sea bream (Sparus aurata) fed with graded levels of vitamin A enriched rotifers (Brachionus plicatilis). Aquaculture, 283 (1): 102-115.

GAFRD (2015). General Authority for Fish Resources Development, Report on fish production, Cairo, Egypt.

Kiron, V. (2012). Fish immune system and its nutritional modulation for preventive health care. Anim. Feed Sci. Technol., 173: 111-133.

Kolk, L.J. and W. Smink, (2005). Non-specific immune stimulation of Bokashi in head kidney cells of carp. Feed Innovation Services (F.I.S.) bv Wageningen.

Kriangsak, P. (2001). Biotechnology for black tiger prawn culture. Rimbo Journal, 30: 22-23.

Labib, Eman H. (2016). Effect of dietary protein levels and carbohydrate sources for water media on live food microbial protein production for Nile tilapia (Oreochromis niloticus). Mediterranean Aquaculture Journal, 8 (1):153-170.

Long, L., Yang, J., Li, Y., Guan, C., and Wu, F. (2015). Effect of biofloc technology on growth, digestive enzyme activity, hematology, and immune response of genetically improved farmed tilapia (Oreochromis niloticus). Aquaculture, doi: 10.1016/j.aquaculture.2015.05.017. 
Lzquierdo, A., Wellman, C. L. and Holmes, A. (2006). Brief uncontrollable stress causes dendritic retraction in infralimbic cortex and resistance to fear extinction in mice. Journal of Neuroscience, 26 (21): 5733-5738.

Mansour, A. T. and Esteban, M. Á. (2017). Effects of carbon sources and plant protein levels in a biofloc system on growth performance, and the immune and antioxidant status of Nile tilapia (Oreochromis niloticus). Fish \& shellfish immunology, 64: 202209.

Moss, S.M., Divakaran, S. and Kim, B.G. (2001). Stimulating effects of pond water on digestive enzyme activity in the Pacific white shrimp, Litopenaeus vannamei (Boone). Aquaculture Research, 32: 125-132.

Nieuwenhuize, J. (2000). Nitrogen uptake by heterotrophic bacteria and phytoplankton in the nitrate-rich Thames estuary. Marine Ecology Progress Series, 203: 13-21.

NRC, (National Research Council) (2011). Nutrient Requirements of Fish and Shrimp. The National Academies Press, Washington, DC. Pp. 57.

Pérez-Fuentes, J. A., Hernández-Vergara, M. P., PérezRostro, C. I. and Fogel, I. (2016). C: N ratios affect nitrogen removal and production of Nile tilapia Oreochromis niloticus raised in a biofloc system under high-density cultivation. Aquaculture, 452: 247-251.

Piedrahita, R. H. (2003). Reducing the potential environmental impact of tank aquaculture effluents through intensification and recirculation. Aquaculture, 226 (1), 35-44.

Rurangwa, E. and Verdegem, M. C. (2015). Microorganisms in recirculating aquaculture systems and their management. Reviews in Aquaculture, 7 (2): 117-130.
Sangakkara, U. R. (2002). The technology of effective microorganisms-Case studies of application. Royal Agricultural College, Cirencester, UK Research Activities.

Shelby, R., Lim, C., Yildirim-Aksoy, M. and Delaney, M.A. (2006). Effects of probiotic diet supplements on disease resistance and immune response of young Nile tilapia, Oreochromis niloticus. J. Appl. Aquac., 18: 49-60.

Tekelioğlu, T. (1998). Koska 90 yaşında: Diyet helvaya ne dersiniz.

Verma, A. K., Rani, A. B., Rathore, G., Saharan, N. and Gora, A. H. (2016). Growth, non-specific immunity and disease resistance of Labeo rohita against Aeromonas hydrophila in biofloc systems using different carbon sources. Aquaculture, 457: 61-67.

Wang, G., Yu, E., Xie, J., Yu, D., Li, Z., Luo, W. and Zheng, Z. (2015). Effect of $\mathrm{C} / \mathrm{N}$ ratio on water quality in zero-water exchange tanks and the biofloc supplementation in feed on the growth performance of crucian carp, Carassius auratus. Aquaculture, 443: 98-104.

Wang, Y. B., Tian, Z. Q., Yao, J. T. and Li, W. F. (2008). Effect of probiotics, Enteroccus faecium, on tilapia (Oreochromis niloticus) growth performance and immune response. Aquaculture, 277 (3): 203-207.

Xia, S., Li, Y., Wang, W., Rajkumar, M., Kumaraguru Vasagam, K. P. and Wang, H. (2010). Influence of dietary protein levels on growth, digestibility, digestive enzyme activity and stress tolerance in white-leg shrimp, Litopenaeus vannamei (Boone, 1931), reared in high-density tank trials. Aquac. Res., 41: 1845-1854.

Zhao, X., Wang, Y., Ye, Z.F. and Ni, J.R. (2006). Kinetics in the process of oil field wastewater treatment by effective microbe B350. China Water Wastewater, 11: $350-357$.

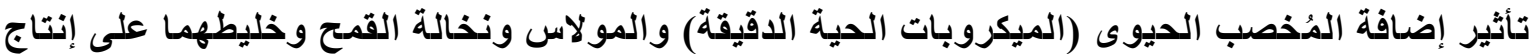

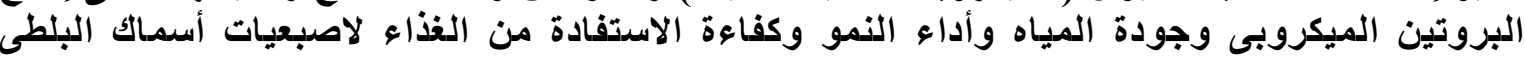

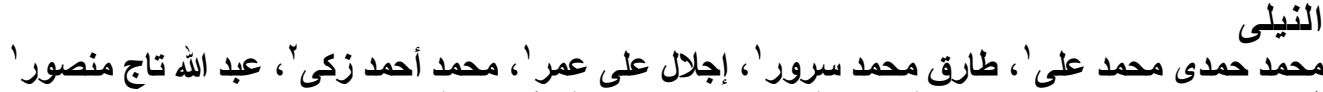

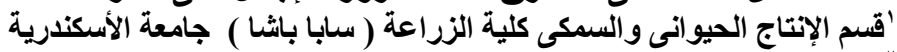

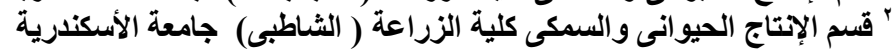

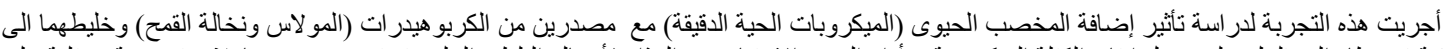

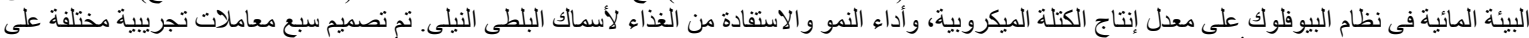

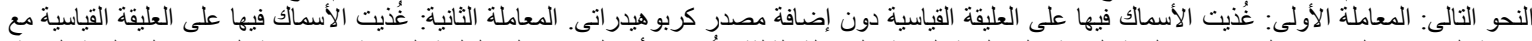

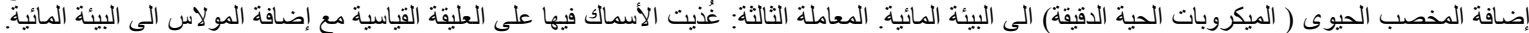

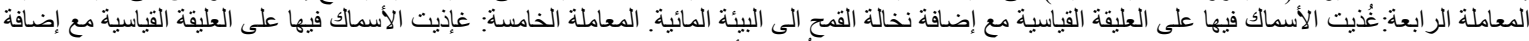

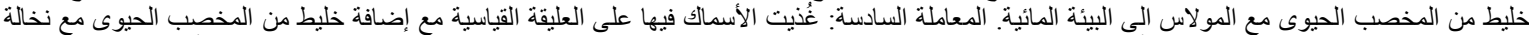

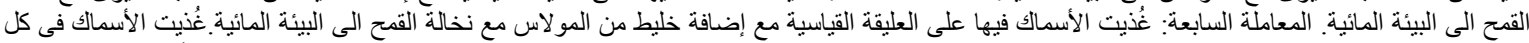

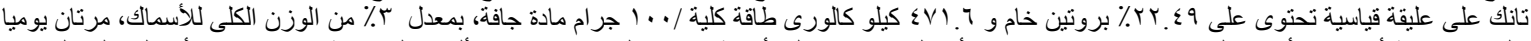

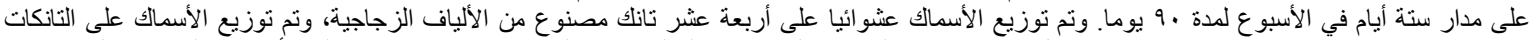

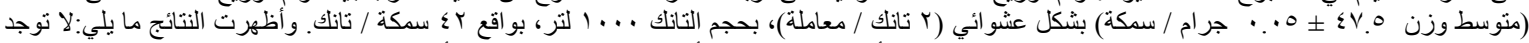

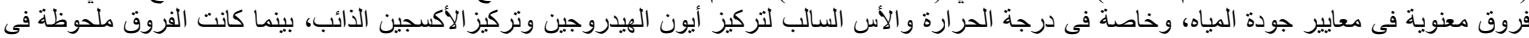

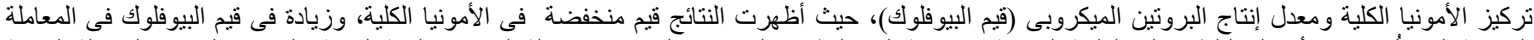

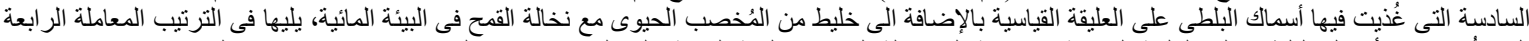

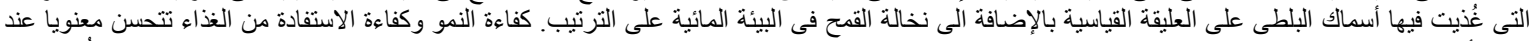

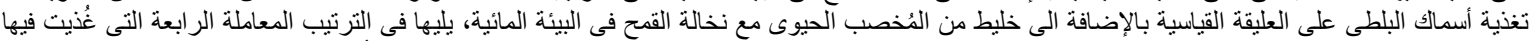

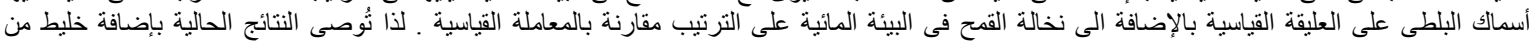

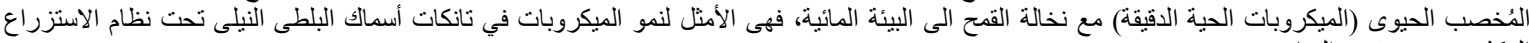

